\title{
Implementation of the Quality Management System in the telecommunications companies
}

\author{
Ekaterina Menshikova ${ }^{1, a}$, Oleg Khazanov ${ }^{2}$, Mark Styazhkin ${ }^{1}$ \\ ${ }^{1}$ Tomsk Polytechnic University, 634050 Lenin Avenue, 30, Tomsk, Russia \\ ${ }^{2}$ Tomsk State University, 634050 Lenin Avenue, 36, Tomsk, Russia
}

\begin{abstract}
This article describes the advantages of the implementing of the quality management system based on ISO 9001 in the telecommunications companies. The stages of the implementation of the quality management system in the telecommunications companies are discussed. The map of the main process and criteria of processes is developed. The expediency of implementing the quality management system based on the requirements of ISO 9001 in Telecommunications is showed.
\end{abstract}

\section{Introduction}

The telecommunications market is one of the most rapidly developing markets in Russia. There is a constant battle for subscribers, the coverage area is expanding, new tariff plans and services are constantly offered. This market is characterized by intense competition: in addition to the federal institutions in the regions, there are local organizations providing communication services. There comes a time when the quality of provider's services determines the customer's choice.

Therefore, the purpose of the organizations which are working in the telecommunications market is constant improving of competitiveness through maximizing satisfaction of the growing needs and expectations of consumers of telecommunications services.

The current stage of development of the methodology of quality encompasses not only problems of the products' and services' quality, but also the quality of management, which is directly responsible for the formation of an appropriate level of the service quality.

As the consequence of this, the companies began to use the quality management system (QMS), having obtained widespread application, which covers all stages of the company. QMS is based on the requirements of International Standard ISO $9001[1,2]$.

The rest of the paper is organized as follows. Section 2 gives the literature review. Section 3 describes the data and the methodology of the process approach. Section 4 presents the results and discussion. Section 5 concludes this paper with some policy implications.

\section{Literature Review}

For the purpose of their successful activity, companies must provide the possibility of realization of the principles of the quality management system, mastered by advanced international companies.

These principles form the basis of the international standards in the field of quality management ISO 9000. According to the version of ISO 9001-2015, the quality management principles are [2]:

- customer focus;

- leadership;

- engagement of people;

- process approach;

- improvement;

- evidence-based decision making;

- relationship management.

The introduction of the quality management system based on ISO 9001 allows [3]

- orientating to the quality goals and methods of management

- increasing the order in the company (in the documentation, regulatory requirements, activity management);

- clearly allocating the powers and responsibilities, regulating the relationship between professionals and departments;

- producing standard requirements for the registration documentation (instructions, rules, regulations, order, etc.);

- defining the requirements for the important processes which affect the quality and placing these

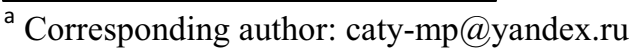


requirements in the form of documented procedures (standards of organization);

- focusing on the prevention of the errors and deviations from the established requirements;

- constantly improving the quality of the provided services and the quality of the staff;

- increasing the responsibility of the employees for the results of their activity;

- improving the company's image;

- increasing the investment attractiveness of the company;

- providing a guarantee in meeting the requirements of consumers.

The creation of QMS should be viewed as a project, which is a unique process, consisting of a set of coordinated and controlled activities, undertaken to achieve a specific goal. Similarly to any project, the creation of the system must meet the specific requirements, including determination of time and resources limits. The project-oriented format of the system makes it possible to ensure effectiveness of these works through focusing on the achievement of specific intermediate (incremental) and ultimate goals, as well as the best use of resources.

\section{Data and Estimation Techniques}

Let us consider the order of implementation of the quality management system in the telecommunications company.

The first task, according to the requirements of ISO 9001, is to identify the processes needed for QMS. Obviously, this formula includes all manufacturing and administrative processes of the company's management, which have a direct or indirect impact on the quality. The practice of identifying the processes by the staff of the companies, that implemented the quality management system according to ISO 9001, shows that establishing of the entire composition of the processes is rarely possible for the first time. As a rule, a temporary version of the list of the processes is initially formed to make it possible to start working on their definition.
Then, as the staff is aware of its duties, the list is adjusted according to the better reflection of the composition of the existing processes.

For the companies operating in the telecommunications market, all the processes can be classified into 4 groups [1]:

1.life cycle processes (basic processes): the direct result is providing services, that are valuable to the consumer and generate revenues for the organization;

2. supporting processes (auxiliary): the result is the creation of the necessary conditions for the implementation of the basic processes;

3. monitoring, analysis and improvement: the result is the information obtained while monitoring and analysis of the organization at all levels of the hierarchy for further improvement of organization's activity;

4. management processes, covering the full range of management functions at the level of each business process and the system as a whole, that is, the set of the interconnectedness of all the processes of the organization. The result of these processes is the achievement of the planned objectives and the increase of the effectiveness and the efficiency of basic and supporting processes.

Standard forms provide information about the inputs and outputs, their suppliers and consumers, the content of the process and its constituent parts (subprocesses). One of the forms of representation of the process is the process's map.

The Process's Map is a graphical representation of the process in the form of a block-diagram, where the process' steps are displayed in predefined columns relevant to stakeholders. Maps of the process should be designed personally by the owners of the processes and with the obligatory involvement of managers and specialists working in their business departments [4].

\section{Empirical Results}

Participants of the processes carry out the identification of their own activities in the framework of the quality management system, using text descriptions, standard forms and process maps (Figure 1).

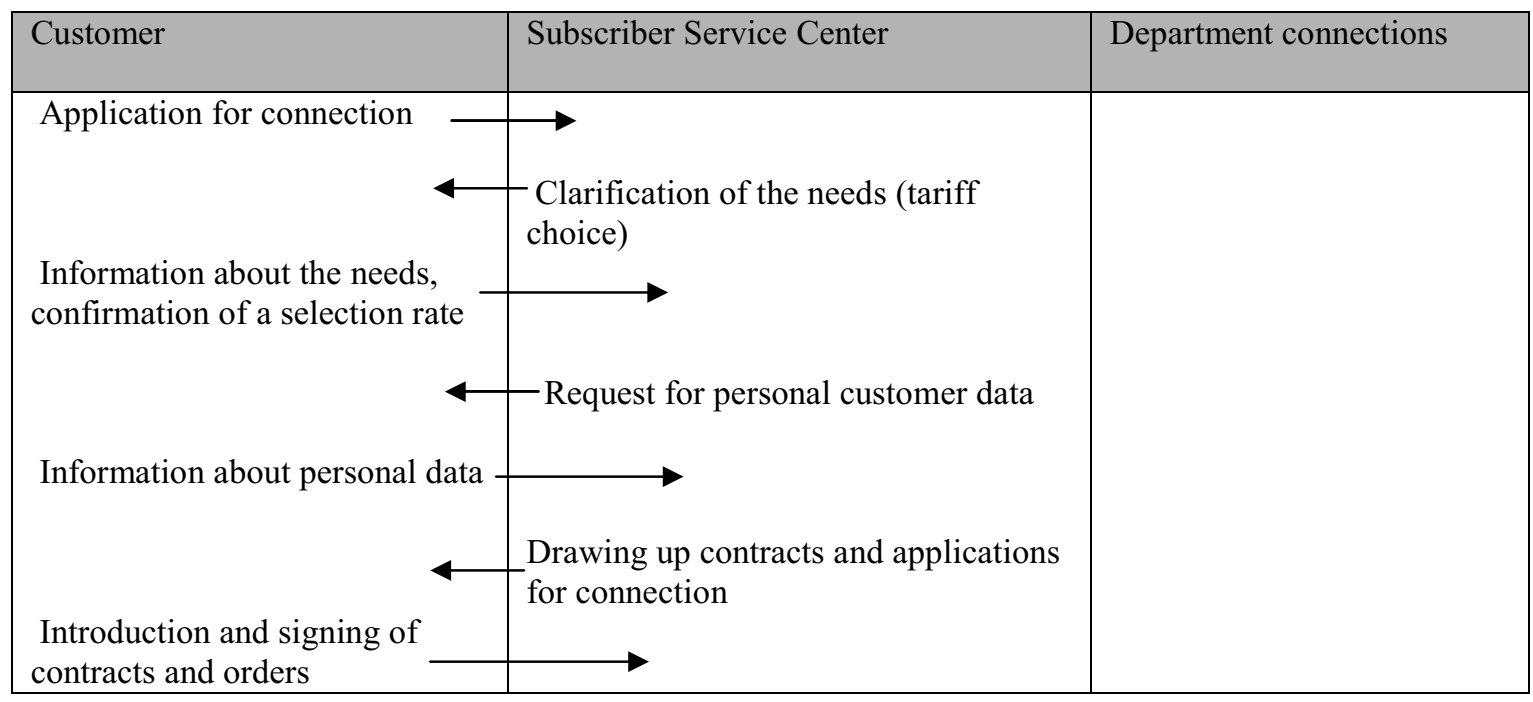




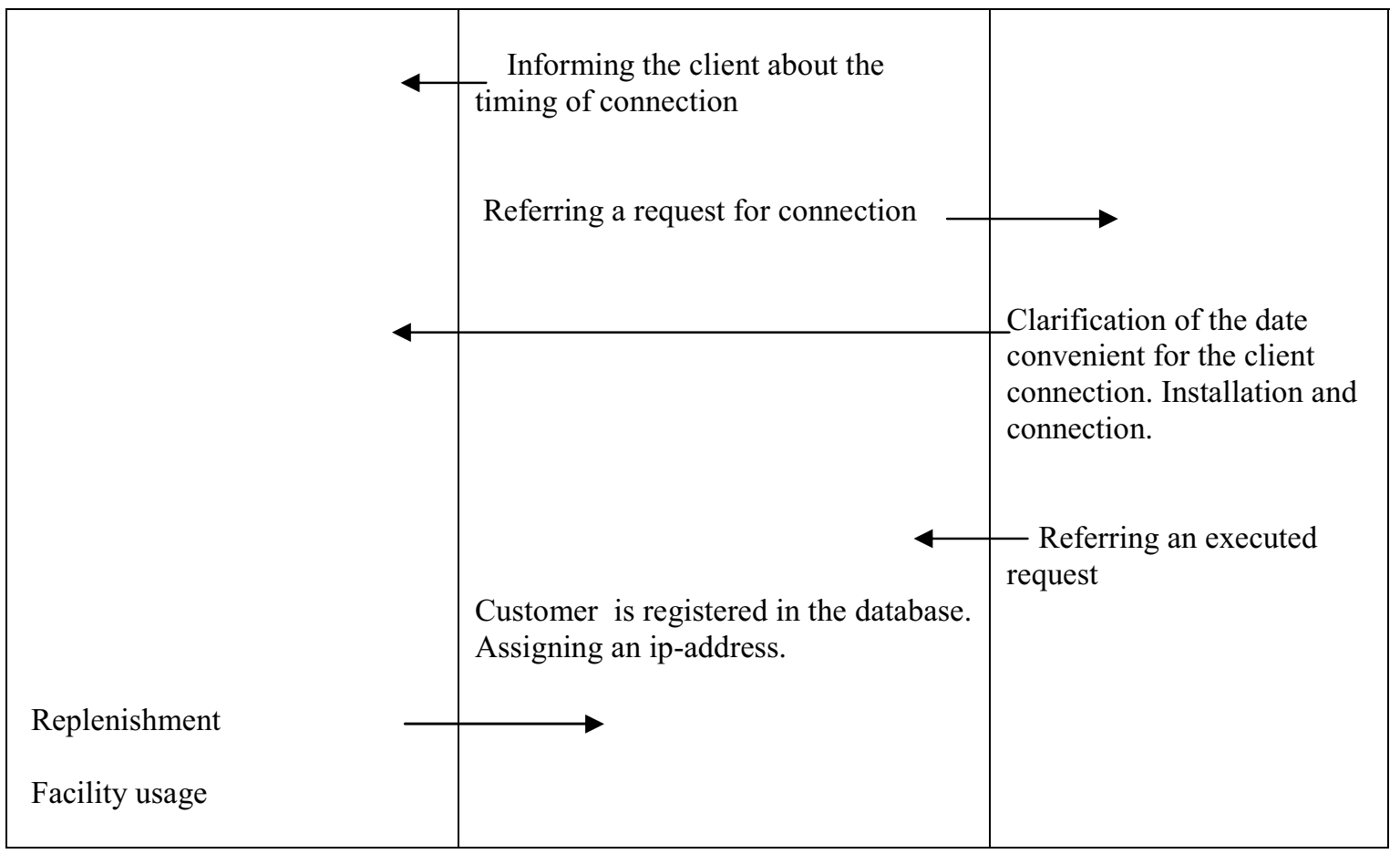

Fig. 1 An example of a process map of subscription to the service

Since the implementation of the Quality Management System is aimed at the organization's focus on customer satisfaction, the telecommunications companies should develop the processes oriented to the solution of the following problems of the management of quality of communication services:

- identifying and removal of the causes of the discrepancies found in the analysis of complaints of consumers of telecommunications services, received by the organization;

- development of the methodology of work with the incoming applications;

- organization of the work with consumers' appeals.

- Development and improvement of measures eliminating the causes of complaints.

The next step is the formation of resource requirements for the functioning of the process. In accordance with the new version of ISO 9001:2015, the resources must be identified and provided. As an essential component of resources, the standard marks, people (managers and contractors), infrastructure, the environment for the functioning of the process, resources, monitoring and measurement, and organizational knowledge. If all of the resources, essential to the desired course of the process, become possible or effective, defined by the tangible and intangible components and used in the process of converting the incoming items into outgoing, then the resources must also include the method of work and time.

At the final stage, indicators of the process are set. In order to establish indicators of each process, it is necessary to determine its long-term objectives in terms of quality. The goals of the processes are to be defined in such a way that each of them fully meets the objectives of the company in terms of quality and achievement of all the goals of the processes in the amount, which is provided for attaining the goals of the company.

The monitoring and the measurement of the processes are carried out in order to confirm the ability of the processes to achieve assigned goals. Monitoring of the processes is performed by the head of the process in accordance with the order, which is laid down in the relevant sections of the Quality Manual.

Objectives of the processes, criteria of their effectiveness, their frequency of measurement are determined and approved by the manager. Monitoring is carried out by analyzing the records of QMS for the certain process and the status of the current reporting period.

During the evaluation and analysis of the quality management system, telecommunications companies should give special attention to the effectiveness of the main production processes, which affect the quality of the service delivery, services and payments to consumers for the telecommunications services, as well as to the auxiliary processes, which affect the quality of the main processes.

The effectiveness of the basic processes is estimated by the management of the realized plans, quantitative and qualitative indicators of the work of the departments, reports on the work with consumers, the quarterly financial statements, statements of sales services, on the basis of comparing the results of the reporting period to the previous period.

Using the received data, management reviews the effectiveness of QMS processes and, if necessary, takes corrective and preventive measures by making a plan of 
corrective and preventive actions. Based on analysis, the decisions, aimed at improving the effectiveness of the QMS and the quality of services, are made.
The system of indicators measuring some of the QMS processes in the telecommunications company is submitted in the form of Table 1.

Table 1. The System of Indicators Measuring Some of the QMS Processes

\begin{tabular}{|c|c|c|c|}
\hline The process & The purpose & $\begin{array}{l}\text { Performance evaluation } \\
\text { process and its results }\end{array}$ & $\begin{array}{l}\text { Who measures the } \\
\text { frequency of } \\
\text { assessment }\end{array}$ \\
\hline Customer service & Quality customer service & $\begin{array}{l}\text { The percentage of } \\
\text { applications made by a } \\
\text { fault, the ratio of } \\
\text { subscriber complaints with } \\
\text { respect to prior periods }\end{array}$ & $\begin{array}{l}\text { Head of Subscriber } \\
\text { Service Center } \\
\text { Once a month }\end{array}$ \\
\hline Connecting to Cable TV & $\begin{array}{l}\text { Fast and high-quality connection } \\
\text { of subscribers }\end{array}$ & $\begin{array}{l}\text { The number of } \\
\text { installations for the period. } \\
\text { The number of complaints } \\
\text { from subscribers when } \\
\text { connecting. }\end{array}$ & $\begin{array}{l}\text { Head of Subscriber } \\
\text { Service Center } \\
\text { Once a month }\end{array}$ \\
\hline Connecting to the Internet & $\begin{array}{l}\text { Fast and high-quality connection } \\
\text { of subscribers }\end{array}$ & $\begin{array}{l}\text { The number of } \\
\text { installations for the period. } \\
\text { The number of complaints } \\
\text { from subscribers when } \\
\text { connected }\end{array}$ & $\begin{array}{l}\text { Head of Subscriber } \\
\text { Service Center } \\
\text { Once a month }\end{array}$ \\
\hline $\begin{array}{l}\text { Connecting the individual } \\
\text { projects of corporate }\end{array}$ & $\begin{array}{l}\text { Fast and high-quality connection } \\
\text { of subscribers }\end{array}$ & $\begin{array}{l}\text { Number of deviations } \\
\text { from the prescribed } \\
\text { deadlines }\end{array}$ & $\begin{array}{l}\text { Corporate department } \\
\text { Once a month }\end{array}$ \\
\hline $\begin{array}{l}\text { Planned maintenance of } \\
\text { cable facilities }\end{array}$ & $\begin{array}{l}\text { Maintaining the network in } \\
\text { working condition (detection of } \\
\text { faults, performance of } \\
\text { preventative maintenance) }\end{array}$ & $\begin{array}{l}\text { The percentage of the } \\
\text { scheduled preventive } \\
\text { maintenance work, the } \\
\text { number of reported faults }\end{array}$ & $\begin{array}{l}\text { Chief engineer } \\
\text { Once a month }\end{array}$ \\
\hline $\begin{array}{l}\text { Provision of the means of } \\
\text { measurement }\end{array}$ & $\begin{array}{l}\text { Ensuring the healthy and } \\
\text { accurate measuring instruments } \\
\text { for industrial processes }\end{array}$ & $\begin{array}{l}\text { The percentage of } \\
\text { defective and proven } \\
\text { means of measurements }\end{array}$ & $\begin{array}{l}\text { Chief engineer } \\
\text { Once a month }\end{array}$ \\
\hline Conducting internal audits & $\begin{array}{l}\text { Demonstration of compliance } \\
\text { with the organization's QMS, the } \\
\text { requirements of ISO 9001: } 2015\end{array}$ & $\begin{array}{l}\text { Number of comments } \\
\text { identified by auditors }\end{array}$ & $\begin{array}{l}\text { Responsible } \\
\text { representative to } \\
\text { establish a QMS }\end{array}$ \\
\hline Customer satisfaction score & $\begin{array}{l}\text { The positive perception of the } \\
\text { quality of services }\end{array}$ & $\begin{array}{l}\text { The number of positive } \\
\text { reviews. The amount of } \\
\text { money claims }\end{array}$ & $\begin{array}{l}\text { Head of Subscriber } \\
\text { Service Center } \\
\text { Once a month }\end{array}$ \\
\hline
\end{tabular}

\section{Concluding Remarks}

The requirements of users of telecommunications services are constantly increasing; telecommunications companies are deeply interested in the identification of consumers' needs and of the analysis of customers' satisfaction.

In order to analyze the overall situation of customers' satisfaction and efficiency of the processes and formation of indicators of the process "Evaluation of customer satisfaction", it is necessary to use the following results:
- market research, which display the degree of satisfaction of consumers of telecommunications services, and the quality of a service of communication services;

- analysis of applications received from customers;

- personal reception of customers;

- $\quad$ surveys;

- $\quad$ analysis of the media.

One of the essential steps of implementing QMS is documenting of the processes. The documentation of the quality management system shall describe the activities of the company, particularly the processes that significantly affect the quality of services provided. A 
documental description of the key processes of activity ensures their traceability, clear understanding, management, and continuous improvement.

Implementation of the QMS, based on the requirements of ISO 9001, will improve the procedure providing the services and the interaction with customers.

The operating quality management system can be a real tool for the continuous improvement of the company and a source of economic benefits. Due to the documenting, monitoring, analysing and periodic reviewing of the key production and management processes in accordance with the international standard, the better manageability and continuous improvement of the company are provided.

\section{References}

1. The state standard of the RF GOST R ISO 90002008 (M., St. 2008)

2. The state standard of the RF GOST R ISO 90012015 (M., St. 2015)

3. Ye.S. Bryukhova, Meth. of QM, 12, 35-42 (2015)

4. J.M. Gómez-Gras, A.J. Verdú-Jover, TQM and Bus. Ex., 16(7), 841-860 (2005)

5. I.D. Subramaniam, Eur. J. of Soc. Sc., 17(4), 638650 (2010) 